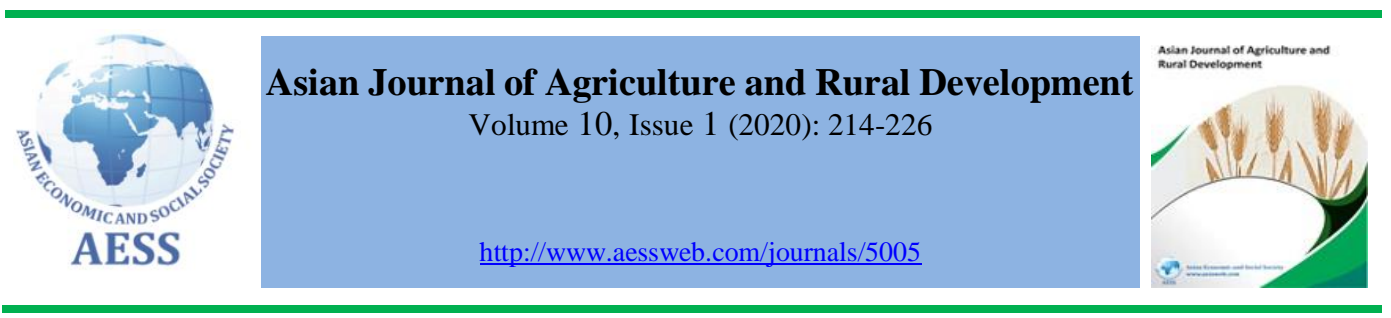

\title{
FACTORS AFFECTING THE MANAGEMENT OF PESTICIDE BUSINESS: THE CASE VIETNAM
}

\author{
Ngo Chi Thanh ${ }^{\text {a }}$ a Lecturer; Faculty of Economics and Business Administration, \\ Hong Duc University, Vietnam \\ ${ }^{\mathrm{b}}$ Lecturer; Faculty of Agriculture, Forestry and Fishery, Hong \\ Le Thi Phuong ${ }^{\mathrm{b}}$ Duc University, Vietnam \\ ${ }^{\mathrm{c}}$ Lecturer; Department of General Administration, Faculty \\ Le Van Cuong ${ }^{\mathrm{c}}$ of Economics and Business Administration, Hong Duc \\ University, Vietnam \\ - levancuong@hdu.edu.vn (Corresponding author)
}

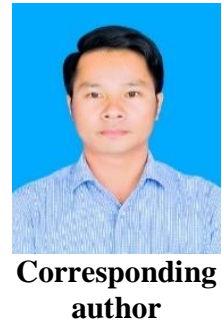

\section{ARTICLE HISTORY: \\ Received: 28-Jan-2020 \\ Accepted: 16-Apr-2020 \\ Online Available: 06-May- 2020}

\section{Keywords:}

Pesticide market,

Business management, Influential factor, Thanh Hoa province, Vietnam economics

\begin{abstract}
Based on the context of Thanh Hoa province, Vietnam, this paper studies the factor affecting the management of pesticide business for the case of Vietnam. The authors propose the model with five factors affecting the management of pesticide business activities in Thanh Hoa province, including (i) Content and implementation methods of the legal documents; (ii) Capacity of the management staff; (iii). Awareness and legal compliance of the pesticide traders; (iv) Budget, infrastructure, and facilities for the pesticide management; and (v) Collaboration between management stakeholders. In this study, 176 pesticide traders were investigated for the 5 mentioned factors in Thanh Hoa province. The question of factors influencing the management of pesticide business activities in the province was done by using Exploratory Factor Analysis and Regression Analysis. The result showed that all the above factors have affected the management of pesticide business in which, the collaboration between the management stakeholders and the awareness and legal compliance of pesticide traders are the most affected while the content and implementation methods of the legal documents are less influence. Based on these results, the paper proposes solutions to improve the management of pesticide trading activities in the coming time in Thanh Hoa province.
\end{abstract}

\section{Contribution/ Originality}

This work significantly contributes to the literature on the management and business of the pesticide. We show crucial factors influence the management of pesticide business. Based on these results, we propose several recommendations for policymakers and provincial governments to a limited negative effect of pesticides used and to develop sustainable agricultural production as well as ensuring human health and environmental protection.

DOI: 10.18488/journal.1005/2020.10.1/1005.1.214.226

ISSN (P): 2304-1455/ISSN (E):2224-4433

How to cite: Ngo Chi Thanh, Le Thi Phuong and Le Van Cuong (2020). Factors affecting the management of pesticide business: the case Vietnam. Asian Journal of Agriculture and Rural Development, 10(1), 214-226.

(C) 2020 Asian Economic and Social Society. All rights reserved. 


\section{INTRODUCTION}

The pesticide is considered as an effective tool in plant pest management. However, the overuse of pesticides is not necessary and does not bring economic efficiency. This situation occurs in many countries, for instance, currently, the use volume of pesticide in the world amounting to 35 million tons/year which equally total value of 45 billion USD (Eyhorn et al., 2015); In which, until 1/3 of this volume does not reach to the standard requirements (Sylviane et al., 2002). From that point of view, the issue of the management of pesticide business is attracting researchers and also the government in several agricultural countries (for instance, see Do et al. (2009); Van et al. (2013).

Thanh Hoa is a province that has a large area of agricultural production and the thriving crop industry (Ngo et al., 2019). This facilitates Thanh Hoa province to be a potential market for pesticide trading with a strong and diversified network of pesticide supply. Up to December 2016, there were 43 companies registered for pesticide business via 07 major distributors, 1,106 retail shops, and about 420 temporary trading households, selling more than 420 pesticide products in this province inadequate (Thanh Hoa Plant Protection Department, 2016). However, this status of remarked development of the pesticide market also causes many difficulties, challenges, and arises inadequacies in the management of pesticide business concerning: (i). The expired, unqualified, and banned pesticides and pesticides with unclear origin are till present on the market; (ii). There is no storage facility for the confiscated and violated drugs; (iii). The knowledge about pesticides of technical local staff, especially communal authorities are insufficient; (iv). Inspection and examination of pesticide business in the province is inadequate (Thanh Hoa Plant Protection Department, 2016). In 2016, 254 pesticide traders were inspected for 8 times by Thanh Hoa Plant Protection Department, of which 30 pesticide traders were reported to violate the common regulations in terms of business ineligibility, unlisted prices, and lack of storage facilities, and selling pesticides together with animal feed (Thanh Hoa Plant Protection Department, 2016).

To improve the effectiveness of pesticide management in the province, it is essential to first identify the factors affecting the management of pesticide business activities. In this study, the authors surveyed to collect data and evaluate the status of management of pesticide trading activities in Thanh Hoa province, combined with the use of Exploratory Factor Analysis (EFA) and regression analysis, aiming to: (i). Identify factors affecting the management of pesticide trading activities in the province; (ii). Analyse the influencing factors of the management of pesticide trading activities; (iii). Propose solutions to improve the management of pesticide trading activities in the coming time in Thanh Hoa province.

\section{LITERATURE REVIEW}

Management of pesticide business requires the involvement of not only the state, but also the coordination between communities and consumers of agricultural products, and the pesticide production and trading companies (FAO, 2002). According to SRV (2001), the management of pesticide business is the management of the special supply-demand relationship since pesticides are considered "a special good with strict limitations in trade" in all nations. Unlike the "supplydemand" relationship of other goods where there is a "demand", there will be a "supply", that of pesticide products will create "demand" when having "supply". Good management of pesticide trading in the side of "supply" will make an important contribution to prevent the un-registered pesticides and ensure a sufficient supply of qualified pesticides on the market (FAO, 2002).

There is vast literature related to the issues of the factor affecting the management of pesticide in general, and particularly in the management of pesticide trading. Van et al. (2001) study the use of pesticides in producing mango which shows that, though the guide of business trader, farmers using more pesticides per year while the yield is not increased. Concerning reducing pesticide use, Eyhorn et al. (2015) pointed out that, the current production system, value chains, and policy 
environment need to be changed. Accordingly, three groups of factors are required to work together to ensure better management of pesticide reduction: availability of and know-how on alternatives, increasing demand for low-/no-pesticide products, and conducive legislation and policies. In other aspects, Holland and Rahman (1999) study about trends of agricultural pesticide used in New Zealand, they mention that several factors are affecting to the using of a pesticide including nature condition, the agricultural system, system of legal documents, technology, knowledge, the capacity of the management staff...; learning for the case of China, Fan et al. (2015) show that: characteristics of farmers, knowledge, behaviours of pesticide traders, the action of government are factors directly affected to pesticide using behaviours of the farmers. Several other studies also focus on pesticides used behavior of farmers, for instance: Tijani (2006) for the case of Nigeria; Ntow et al. (2006) for the case of Gana; Williamson et al. (2003) for the case of India and Kenya, or Zhou and Jin (2009) for the case of China.

In Vietnam, although there is an increase in the number of studies on the subject of pesticide using and trading, however, the issue of the factor affecting the management of pesticide business is still limited. Adjrah et al. (2013), Van et al. (2009) analyze factors affecting to behaviours of farmers in using a pesticide. The study shows that farmers knowing pesticide by training normally taking care of the brand name of the pesticide; Van et al. (2013) indicate that, an overall improvement of pesticide business management only relies on better government intervention, focusing on more stringent implementation and enforcement of regulation. Several other studies, for instance, Mengistie et al. (2015); Hoi et al. (2016); Nguyen et al. (2013); Nguyen et al. (2018) also emphasize to five main factors affecting the implementation of regulations on the management of pesticide business, including state policies, management apparatus, awareness of pesticide traders, dissemination activities and inspection activities of pesticide business.

According to the author's knowledge, the issue of studying factors affecting to the management of pesticide business has not been done for the case of Thanh Hoa province, and there is still limited literature studying by quantitative methods to address the question of influencing factors to the management of pesticide business in Vietnam.

\section{METHODOLOGY}

\subsection{The model and hypotheses}

\subsubsection{Overview of pesticide business and management in Thanh Hoa province}

Based on the secondary data collected from the Plant Protection Department of Thanh Hoa province and the survey results obtained from 4 pesticide distribution companies (level 1suppliers), the number of pesticide suppliers in the province within the period 2016-2018 is described in table 1 .

Table 1: Current situation of pesticide business in Thanh Hoa province period 2016-2018

\begin{tabular}{|c|c|c|c|c|c|c|c|}
\hline \multirow{3}{*}{ Year } & \multirow{3}{*}{$\begin{array}{l}\text { Distributors } \\
\text { (level 1- } \\
\text { suppliers) }\end{array}$} & \multicolumn{5}{|c|}{$\begin{array}{l}\text { Level 2-suppliers/ shops } \\
\text { (Distributors) }\end{array}$} & \multirow{3}{*}{$\begin{array}{c}\text { Household } \\
\text { business } \\
\text { (household) }\end{array}$} \\
\hline & & \multirow[t]{2}{*}{$\begin{array}{c}\text { Total } \\
\text { number } \\
\text { (distributor) }\end{array}$} & \multicolumn{2}{|c|}{$\begin{array}{c}\text { Distributors having a } \\
\text { technical certificate } \\
\text { for pesticide }\end{array}$} & \multicolumn{2}{|c|}{$\begin{array}{l}\text { Distributors having } \\
\text { a certificate of } \\
\text { eligible pesticide } \\
\text { business }\end{array}$} & \\
\hline & & & Quantity & Ratio (\%) & Quantity & Ratio (\%) & \\
\hline 2014 & 6 & 616 & 434 & 70.45 & 40 & 6.49 & 182 \\
\hline 2015 & 7 & 838 & 638 & 76.13 & 140 & 21.94 & 200 \\
\hline 2016 & 7 & 1106 & 786 & 71.07 & 428 & 38.07 & 420 \\
\hline 2018 & 7 & 1267 & 1056 & 83.34 & 863 & 68.11 & 244 \\
\hline
\end{tabular}


The number of pesticide traders in Thanh Hoa province is relatively high and tends to increase sharply (from 612 distributors/ shops and 182 retail households in 2014 to 1267 distributors/shops and over 244 retail households in 2018). In 2018, the rate of pesticide distributors/ shops doing business without having a technical certificate for pesticide is relatively high, nearly by $32 \%$. Noticeably, there are still 244 temporary household traders who don't have a technical certificate for pesticide and a certificate of eligible pesticide business, accounting for over $16 \%$ of the total number of pesticide distributors/ shops in the area. This rate is considered as much higher than that of the surrounding provinces such as Hanoi, Hai Phong and Hai Duong which is ranging from 8 to $11 \%$ (Nguyen et al., 2013).

Table 2: Current situation of pesticide business management in Thanh Hoa province

\begin{tabular}{|c|c|c|c|}
\hline Description & 2016 & 2017 & 2018 \\
\hline \multicolumn{4}{|l|}{ 1. Issuance and dissemination of legal documents ${ }^{1}$} \\
\hline - State Legal Normative Documents (Law, Decree, Circular) & \multirow{2}{*}{\multicolumn{3}{|c|}{$\begin{array}{c}17 \text { documents } \\
\text { (1 law; } 4 \text { decrees và } 12 \text { circulars) } \\
15 \text { documents } \\
\text { (1 resolution, } 2 \text { directives, } 1 \text { plans, } 9 \\
\text { decisions; } 2 \text { official letters) }\end{array}$}} \\
\hline $\begin{array}{l}\text { - Provincial Legal Normative Documents (Resolution, Directive, } \\
\text { Plan, Regulation, Official Letter ...) }\end{array}$ & & & \\
\hline \multicolumn{4}{|l|}{ 2. Plan building for business management } \\
\hline $\begin{array}{l}\text { - Plan for inspection (batch) } \\
\text { - Plan for the training of knowledge and skills of pesticide } \\
\text { business management (class) }\end{array}$ & $\begin{array}{c}7 \\
14\end{array}$ & $\begin{array}{c}12 \\
8\end{array}$ & $\begin{array}{c}9 \\
13\end{array}$ \\
\hline \multicolumn{4}{|l|}{$\begin{array}{l}\text { 3. Organization of training course and dissemination in } \\
\text { business management }\end{array}$} \\
\hline $\begin{array}{l}\text { - Training on professional knowledge of pesticide } \\
\text { management }\end{array}$ & 2 & 3 & 6 \\
\hline - Training on legal documents of pesticide business & 7 & 5 & 6 \\
\hline - Providing legal normative documents (leaflets) & 1500 & 1800 & 2400 \\
\hline \multicolumn{4}{|l|}{ 4. Business inspection and handling of violations } \\
\hline - Number of inspection (batch) & 6 & 11 & 8 \\
\hline - Number of inspected distributors/ trader (distributor) & 361 & 310 & 254 \\
\hline - Violated distributors/ traders (distributor) & $\begin{array}{c}83 \\
(22.99 \%)\end{array}$ & $\begin{array}{c}48 \\
(15.48 \%)\end{array}$ & $\begin{array}{c}30 \\
(11.81 \%)\end{array}$ \\
\hline
\end{tabular}

The management of pesticide business in Thanh Hoa province is performed under Vietnamese legal documents which are recommended to the Department of Agriculture and Rural Development by the Department of Plant Protection for the implementation. Up to December 2018, the system of legal documents concerning pesticide management in Thanh Hoa province consists of 17 national normative documents and 15 legal documents issued by provincial authorities.

\subsubsection{The model and hypotheses}

According to Eyhorn et al. (2015), Holland and Rahman (1999), Van et al. (2013) and based on the context of Thanh Hoa province, the author propose the model of affecting factor to the management of pesticide business as the figure following:

In this model, the author proposes five factors affecting to the management of pesticide business, including (i) Capacity of the management staff; (ii) Content and implementation methods of the legal documents; (iii) Awareness and legal compliance of the pesticide traders; (iv) Collaboration between the management stakeholders; and (v) Budget, infrastructure Budget, infrastructure and facilities.

${ }^{1}$ Update in $12 / 2018$ 
The regression model has presented as follows:

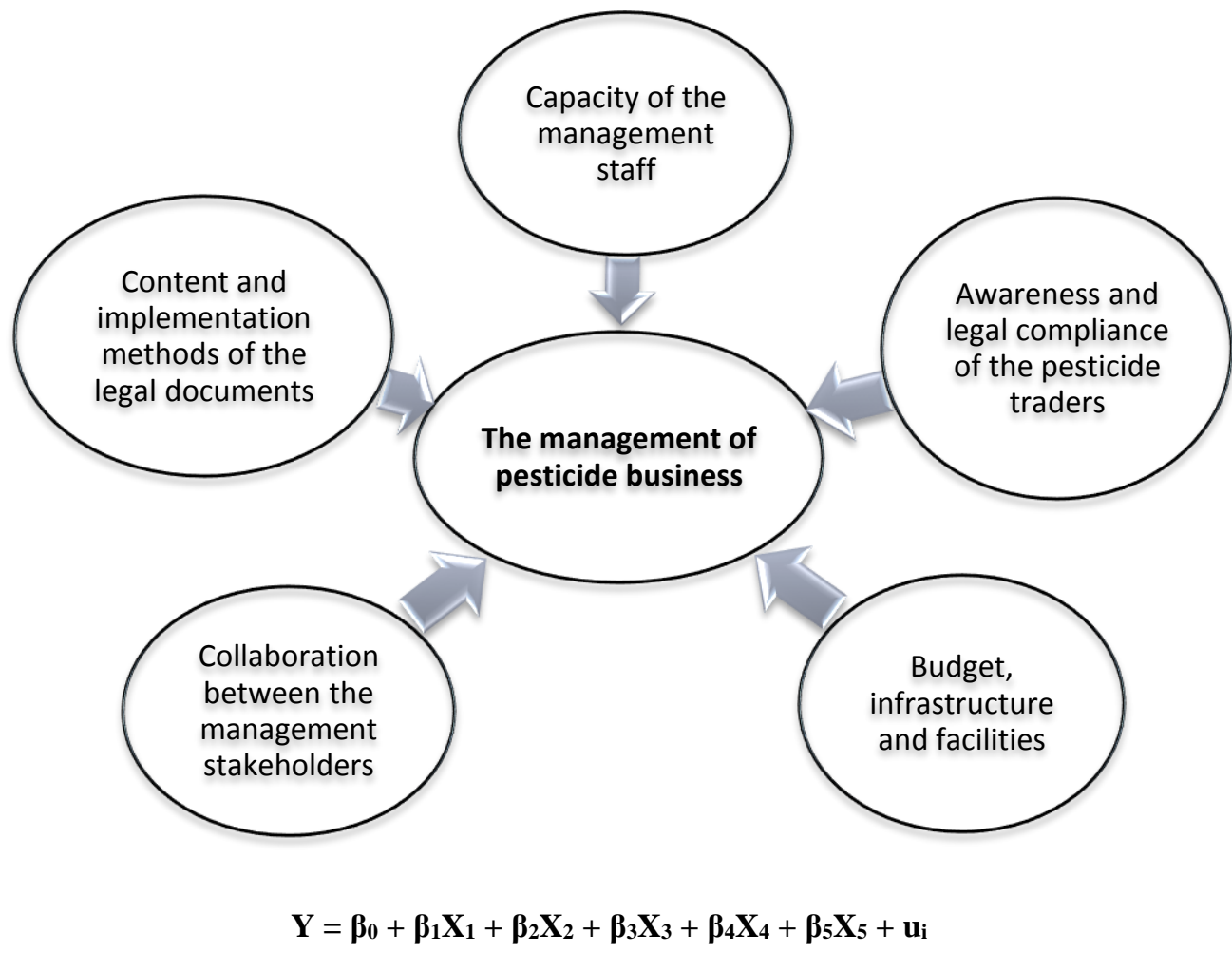

In which: Y: The dependent variable (Outcomes of pesticide business management)

$\mathrm{X}_{\mathrm{i}}$ : The independent variable groups

$\mathrm{u}_{\mathrm{i}}$ : The residual

\section{Hypotheses:}

H1: Content and implementation methods of the legal documents have a positive effect on the management of pesticide business.

H2: The capacity of the management staff has a positive effect on the management of pesticide business.

H3: Awareness and legal compliance of the pesticide traders have a positive effect on the management of pesticide business.

H4: Budget, infrastructure and facilities for the pesticide management have a positive effect on the management of pesticide business.

H5: Collaboration between the management stakeholders has a positive effect on the management of pesticide business.

\subsection{Data and observation variables description}

According to Hair et al. (1998), Hair et al. (2009), the sample size affects the generality of the study results by the ratio of observed variables to the independent variables and there should be 5 observed variables for each independent variable in the difference. In order to reach the desired level of the study and achieve the generalized results, there must be 15-20 observations per an independent variable (Hair et al., 1998; Hoang and Chu, 2008). This study consists of 5 independent variables so it is necessary to have at least 120 observations. Therefore, the database used for analysis and assessment was collected by surveying 176 pesticide traders in 5 
representative districts in Thanh Hoa province, namely Ngoc Lac, Tho Xuan and Thieu Hoa, Hoang Hoa districts and Thanh Hoa city. The Likert scale from 1 to 5 was used to evaluate the influencing factors by the pesticide traders (the scales are indicated as 1 - Strongly disagree; 2 - Disagree; 3 Confused; 4 - Agree; and 5 - Strongly agree), corresponding to 05 groups of factors with 27 observational variables, as presented in table 3 .

Table 3: Description of observational variables within the groups of influencing factors

\begin{tabular}{|c|c|c|}
\hline Factors & Observational variables & $\begin{array}{l}\text { Variable } \\
\text { codes }\end{array}$ \\
\hline \multirow{7}{*}{$\begin{array}{l}\text { 1. Content and } \\
\text { implementation methods } \\
\text { of the legal documents } \\
\left(\mathrm{X}_{1}\right)\end{array}$} & Overlapping legal texts & CS.1 \\
\hline & Gaps/loopholes in legal documents & CS. 2 \\
\hline & Formalism in the dissemination of legal documents & CS.3 \\
\hline & Inappropriate contents of legal documents & CS.4 \\
\hline & Unclear decentralization in management & CS.5 \\
\hline & Non-deterrent sanctions & CS.6 \\
\hline & Rapid changes in the list of pesticides licensed for use & CS.7 \\
\hline \multirow{4}{*}{$\begin{array}{l}\text { 2. Capacity of the } \\
\text { management staff }\left(\mathrm{X}_{2}\right)\end{array}$} & Weak qualification of management staff & NL1 \\
\hline & A few numbers of management staff & NL2 \\
\hline & Management capacity of the local authority & NL3 \\
\hline & Partial inspection officials & NL4 \\
\hline \multirow{7}{*}{$\begin{array}{l}\text { 3. Awareness and legal } \\
\text { compliance of the } \\
\text { pesticide traders }\left(\mathrm{X}_{3}\right)\end{array}$} & Regulations for trading and using pesticides & HB1 \\
\hline & The list of pesticides licensed for use & HB2 \\
\hline & Regulations for the pesticide storage & HB3 \\
\hline & Regulations for the location of pesticide shop & HB4 \\
\hline & $\begin{array}{l}\text { Regulations for other products banned to trade together with } \\
\text { pesticides }\end{array}$ & HB5 \\
\hline & $\begin{array}{l}\text { Regulations for the eligibility of having the technical } \\
\text { certificate for pesticides }\end{array}$ & HB6 \\
\hline & $\begin{array}{l}\text { Reading and providing the guidance of pesticide use for } \\
\text { the buyers }\end{array}$ & HB7 \\
\hline \multirow{6}{*}{$\begin{array}{l}\text { 4. Budget, infrastructure } \\
\text { and facilities for the } \\
\text { pesticide management } \\
\left(\mathrm{X}_{4}\right)\end{array}$} & Limited budgets, mainly from the state & KP1 \\
\hline & Insufficient annual fund for the pesticide traders & KP2 \\
\hline & Limited socializing funds & KP3 \\
\hline & Limited allowances & KP4 \\
\hline & Inadequate equipment and facilities & KP5 \\
\hline & Lack of infrastructure & KP6 \\
\hline \multirow{3}{*}{$\begin{array}{l}\text { 5. Collaboration } \\
\text { between the } \\
\text { management } \\
\text { stakeholders }\left(\mathrm{X}_{5}\right)\end{array}$} & $\begin{array}{l}\text { Collaboration in licensing the certificate for pesticide } \\
\text { business }\end{array}$ & PH1 \\
\hline & Interdisciplinary inspection & $\mathrm{PH} 2$ \\
\hline & $\begin{array}{l}\text { Coordination between management and dissemination of } \\
\text { communal authorities. }\end{array}$ & PH3 \\
\hline \multirow{3}{*}{$\begin{array}{l}\text { 6. Outcomes of pesticide } \\
\text { management }(Y)\end{array}$} & Eligibility for running pesticide business & KQ1 \\
\hline & $\begin{array}{l}\text { Doing appropriate business following the list pesticides } \\
\text { permitted for use. }\end{array}$ & KQ2 \\
\hline & Appropriate handling of damaged pesticides and packaging & KQ3 \\
\hline
\end{tabular}

Data processing was done by using Excel tools and statistic software SPSS 22. Three methods used to analyze data were the statistical description, the exploratory factor analysis and the regression 
analysis. The exploratory factor analysis (EFA) was used to sort groups of factors with variable conditions. The observational variables which have a factor loading index less than 0,05 in the EFA were eliminated. This was done along with the Kaiser-Meyer-Olkin (KMO) test $(\geq 0,5)$. Bartlett's test has a significant value of less than 0,05. The Cronbach Alpha correlation between the xij component variables and the factor group's total variable Xi (group average) has a value greater than 0,3. Cronbach's Alpha correlation coefficient of each variable has a value of 0,6 or higher (Hair et al., 1998; Hoang and Chu, 2008). After sorting the factor groups, the regression analysis was done to determine the impact of the factor groups on the outcomes of pesticide business management $(\mathrm{Y})$.

\section{EMPIRICAL RESULT}

\subsection{Result of Cronbach's alpha and exploratory factor analysis}

To determine the groups of factors affecting the management outcomes of pesticide business in Thanh Hoa province, we used the exploratory factor analysis with 27 observational variables belonging to 5 groups of influencing factors, using a Likert scale. The average scores of variables according to the Likert scale are summarized in table 4.

Table 4: Summary of the evaluation on the management of pesticide business by pesticide traders in Thanh Hoa province

\begin{tabular}{lccc}
\hline Description & $\begin{array}{c}\text { Observational } \\
\text { variables }\end{array}$ & Average score & $\begin{array}{c}\text { Standard } \\
\text { deviation }\end{array}$ \\
\hline & CS.1 & 2,24 & 1,08 \\
1. Content and implementation & CS.3 & 2,82 & 1,05 \\
methods of the legal documents & CS.4 & 3,05 & 1,17 \\
(X) & CS.5 & 2,90 & 1,05 \\
& CS.6 & 2,97 & 1,20 \\
& CS.7 & 2,48 & 0,83 \\
& NL1 & 2,85 & 1,00 \\
2. Capacity of the management & NL2 & 2,80 & 1,17 \\
staff $\left(X_{2}\right)$ & NL3 & 2,56 & 1,06 \\
& NL4 & 2,42 & 1,03 \\
& HB1 & 2,77 & 1,20 \\
3. Awareness and legal & HB2 & 2,10 & 0,72 \\
compliance of the pesticide & HB3 & 2,22 & 0,77 \\
traders $\left(X_{3}\right)$ & HB4 & 2,16 & 0,74 \\
& HB5 & 2,09 & 0,64 \\
& HB6 & 2,06 & 0,71 \\
& HB7 & 1,98 & 0,69 \\
5. Collaboration between the & KP1 & 1,96 & 0,75 \\
management stakeholders $\left(X_{5}\right)$ & KP2 & 1,97 & 0,59 \\
4. Budget, infrastructure and & KP3 & 2,03 & 0,51 \\
facilities for the pesticide & KP4 & 2,08 & 0,57 \\
management $\left(X_{4}\right)$ & KP5 & 1,97 & 0,65 \\
& KP6 & 2,31 & 0,87 \\
& PH3 & 2,32 & 0,83 \\
& & 2,60 & 0,95 \\
\hline
\end{tabular}




\begin{tabular}{llll}
\hline 6. Outcomes of pesticide & KQ1 & 2,31 & 0,55 \\
management (Y) & KQ2 & 2,69 & 0,65 \\
& KQ3 & 2,33 & 0,87 \\
\hline
\end{tabular}

The result of conducting Cronbach's alpha reliability shows that there are 3 observational variables eliminated due to nonconformity, namely: HB7- Reading and providing the guidance of pesticide use for the buyers, PH3- Coordination between management and dissemination of communal authorities and CS1 - Overlapping legal texts.

The remained number of observational variables is 24 which are rearranged into 5 affecting factors (Table 5). All selected variables have values of factor loading coefficient greater than 0,5, KMO coefficient is greater than 0,8 , Figen values greater than 1 , and the variance extracted of $71,03 \%$, suggesting that 5 groups of factors with 24 observational variables are completely suitable and statistically significant.

Table 5: The matrix of factor loading coefficient within the factors affecting the outcomes of management of pesticide business in Thanh Hoa province

\begin{tabular}{|c|c|c|c|c|c|}
\hline \multirow{2}{*}{$\begin{array}{l}\text { Observational } \\
\text { variables }\end{array}$} & \multicolumn{5}{|c|}{ Groups of influential factors } \\
\hline & 1 & 2 & 3 & 4 & 5 \\
\hline HB3 & 0.852 & & & & \\
\hline HB4 & 0.832 & & & & \\
\hline HB5 & 0.796 & & & & \\
\hline HB 1 & 0.792 & & & & \\
\hline HB2 & 0.791 & & & & \\
\hline HB6 & 0.762 & & & & \\
\hline CS.2 & & 0.820 & & & \\
\hline CS.3 & & 0.819 & & & \\
\hline CS.4 & & 0.804 & & & \\
\hline CS.7 & & 0.800 & & & \\
\hline CS.5 & & 0.795 & & & \\
\hline NL1 & & & 0.896 & & \\
\hline NL2 & & & 0.864 & & \\
\hline NL4 & & & 0.665 & & \\
\hline NL3 & & & 0.633 & & \\
\hline KP6 & & & & 0.868 & \\
\hline KP5 & & & & 0.808 & \\
\hline $\mathrm{PH} 2$ & & & & 0.707 & \\
\hline CS.6 & & & & 0.702 & \\
\hline PH1 & & & & 0.569 & \\
\hline KP3 & & & & & 0.820 \\
\hline KP2 & & & & & 0.820 \\
\hline KP1 & & & & & 0.749 \\
\hline KP4 & & & & & 0.600 \\
\hline Variance extracted & 17.527 & 16.119 & 13.378 & 12.370 & 11.634 \\
\hline $\begin{array}{l}\text { Cronbach's Alpha } \\
\text { coefficient }\end{array}$ & 0.904 & 0.897 & 0.861 & 0.835 & 0.797 \\
\hline
\end{tabular}

Note: The groups are ordered from high to low according to the value of factor loading coefficient of observational variables 


\subsection{Regression analysis}

The results from Table 5 indicate that some component variables change their positions within groups 4 and 5. Based on the results of the statistic test and regrouping of the influencing factors, we rearranged the order of influencing factors, as follows:

$\mathrm{X}_{1}$ : Awareness and legal compliance of the pesticide traders (with 6 observational variables: HB3, HB4, HB5, HB1, HB2, HB6)

$\mathrm{X}_{2}$ : Content and implementation methods of the legal documents (with 5 observational variables: CS2, CS3, CS4, CS7 and CS5)

$\mathrm{X}_{3}$ : Capacity of the management staff (with 4 observational variables: NL1, NL2, NL4 and NL3)

$\mathrm{X}_{4}$ : Collaboration between the management stakeholders (with 5 observational variables: KP6, KP5, PH2, CS.6 and PH1)

$\mathrm{X}_{5}$ : Budget, infrastructure and facilities for the pesticide management (with 4 observational variables: KP3, KP2, KP1 and KP4).

Using multiple regression functions with 5 independent variables corresponding to 5 factors were tested and rearranged and the dependent variables corresponding to the outcomes of management of pesticide business, combined with the data obtained from the survey of 176 pesticide traders appraised by the management officials in Thanh Hoa province, we analyzed the regression model using statistic software SPSS.22. The coefficients $\beta$ o - $\beta$ i of the model are summarized in Table 6 .

Table 6: Coefficients of factors affecting the outcomes of pesticide business management in Thanh Hoa province

\begin{tabular}{lccc}
\hline Explanation & Variable & Coefficient & Sig \\
\hline The intercept & & $0,610^{* * *}$ &, 000 \\
Awareness and legal compliance of the pesticide traders & $\mathrm{X}_{1}$ & $0,185^{* * *}$ &, 000 \\
Content and implementation methods of the legal documents & $\mathrm{X}_{2}$ & $0,073^{* *}$ &, 003 \\
Capacity of the management staff & $\mathrm{X}_{3}$ & $0,171^{* * *}$ &, 000 \\
Collaboration between the management stakeholders & $\mathrm{X}_{4}$ & $0,214^{* * *}$ &, 000 \\
Budget, infrastructure and facilities for the pesticide management & $\mathrm{X}_{5}$ & $0,155^{* * *}$ &, 001 \\
$\mathrm{R}^{2}$ & & 0,684 & \\
$\mathrm{~F}$ & & 73,440 & \\
Sig (F) & & 0,000001 & \\
\hline
\end{tabular}

Note: $* *$ and $* * *$ refer to as the significance levels of $5 \%$ and $1 \%$, respectively

The $\mathrm{R}$ square $\left(\mathrm{R}^{2}\right)$ is 0.684 , revealing that 5 -factor groups used for this model affected the management of pesticide business by $68.40 \%$. The coefficients $\beta_{\mathrm{i}}(\mathrm{i}=1-5)$ of the independent variables $\left(\mathrm{X}_{\mathrm{i}}\right)$ are statistically high at a significance level of $99.9 \%$. We observe that all hypotheses are accepted and the regression function, therefore, demonstrates this relationship as follows:

$$
Y=0.610+0.185 X_{1}+0.073 X_{2}+0.171 X_{3}+0.214 X_{4}+0.15 X_{5}+u_{i}
$$

The coefficients $\beta_{\mathrm{i}}$ are all positive, meaning that those factors affect the outcome of pesticide business management in the same direction. Therefore, the improvement of any influential factors would lead to better management outcomes. Among the influential factors, the coefficient for the collaboration between the management stakeholders $\left(X_{4}\right)$ has the highest of value, 0.214 , followed by ones for the awareness and legal compliance of the pesticide traders $\left(X_{1}\right)$ with $\beta_{1}=0.185$, the 
capacity of the management staff $\left(X_{3}\right)$ with $\beta_{3}=0.171$ and the budget, infrastructure and facilities for the pesticide management $\left(X_{5}\right)$ with $\beta_{5}=0.155$. The lowest value is for the coefficient of the content and implementation methods of the legal documents $\left(X_{2}\right)$ with $\beta_{2}=0.073$.

The level of effect for the criteria in each group was determined by the regression analysis of the relationship between the observational variables (each group's criteria) and the groups of factors, as summarized in Table 7.

Table 7: Factors affecting the outcomes of pesticide business management in Thanh Hoa province

\begin{tabular}{|c|c|c|c|c|c|c|c|c|c|}
\hline \multicolumn{2}{|c|}{$\begin{array}{c}\mathrm{X}_{1} \text { : Awareness } \\
\text { and legal } \\
\text { compliance of } \\
\text { the pesticide } \\
\text { traders }\end{array}$} & \multicolumn{2}{|c|}{$\begin{array}{l}\mathrm{X}_{2} \text { : Content and } \\
\text { implementation } \\
\text { methods of the } \\
\text { legal documents }\end{array}$} & \multicolumn{2}{|c|}{$\begin{array}{c}X_{3} \text { : Capacity of } \\
\text { the management } \\
\text { staff }\end{array}$} & \multicolumn{2}{|c|}{$\begin{array}{c}\mathrm{X}_{4}: \\
\text { Collaboration } \\
\text { between the } \\
\text { management } \\
\text { stakeholders }\end{array}$} & \multicolumn{2}{|c|}{$\begin{array}{c}\text { X: Budget, } \\
\text { infrastructure } \\
\text { and facilities for } \\
\text { the pesticide } \\
\text { management }\end{array}$} \\
\hline $\begin{array}{l}\text { Varia } \\
\text { ble } \\
\text { code }\end{array}$ & $\begin{array}{c}\text { Coeffic } \\
\text { ient } \\
\left(\mathrm{X}_{1}\right)\end{array}$ & $\begin{array}{l}\text { Variab } \\
\text { le code }\end{array}$ & $\begin{array}{c}\text { Coeffic } \\
\text { ient } \\
\left(\mathbf{X}_{2}\right)\end{array}$ & $\begin{array}{l}\text { Variab } \\
\text { le code }\end{array}$ & $\begin{array}{c}\text { Variab } \\
\text { le code } \\
\left(\mathrm{X}_{3}\right)\end{array}$ & $\begin{array}{c}\text { Variab } \\
\text { le } \\
\text { codes }\end{array}$ & $\begin{array}{c}\text { Variab } \\
\text { le code } \\
\left(\mathrm{X}_{4}\right)\end{array}$ & $\begin{array}{c}\text { Variab } \\
\text { le } \\
\text { codes }\end{array}$ & $\begin{array}{c}\text { Variab } \\
\text { le code } \\
\left(X_{5}\right)\end{array}$ \\
\hline HB1 & 0.212 & $\overline{C S}$ & 0.306 & $\mathrm{NL}$ & 0.363 & CS6 & 0.267 & KP1 & 0.299 \\
\hline HB2 & 0.221 & $\mathrm{CS}$ & 0.229 & NL & 0.325 & KP5 & 0.296 & KP2 & 0.349 \\
\hline HB3 & 0.231 & CS4 & 0.217 & NL3 & 0.199 & KP6 & 0.323 & KP3 & 0.338 \\
\hline HB4 & 0.205 & CS5 & 0.194 & NL4 & 0.210 & PH1 & 0.168 & KP4 & 0.216 \\
\hline HB5 & 0.192 & CS7 & 0.240 & & & PH2 & 0.260 & & \\
\hline HB6 & 0.171 & & & & & & & & \\
\hline
\end{tabular}

Source: Result from survey data of author (2018)

Regarding the awareness and legal compliance of the pesticide traders $\left(X_{I}\right)$, the most influencing component is the mastery of regulations for the pesticide storage (HB3), followed by that of the list of pesticides licensed for use (HB2). The regulation for the eligibility of having the technical certificate for pesticides (HB1) is ranked as the least influencing component. In term of the content and implementation methods of the legal documents $\left(X_{2}\right)$, the biggest impacting component is the gaps/loopholes in the legal documents (CS2), followed by the rapid changes in the list of pesticides licensed for use (CS7) and the unclear decentralization in management (CS5).

Concerning the capacity of the management staff $\left(X_{3}\right)$, the most influential component is the weak qualification of management staff (NL1), followed by the low number of management staff. The management capacity of the local authority (NL3) is considered as the smallest influencing component.

In term of the budget, infrastructure and facilities for the pesticide management $\left(X_{4}\right)$, the most influential component is the lack of infrastructure (KP6), followed by the inadequate equipment and facilities (KP5) and the collaboration in licensing the certificate for pesticide business (PH1) is ranked as the least influencing one. For the budget, infrastructure and facilities for pesticide management $\left(X_{5}\right)$, the most influential component is the insufficient annual training fund for the pesticide traders (KP2), followed by the limited socializing funds (KP3) and the lowest influencing one is the limited allowances (KP4).

Our results correspond to the studies of Holland and Rahman (1999), Van et al. (2013) and Eyhorn et al. (2015) who emphasize that agricultural system, a system of legal documents, technology, knowledge, the capacity of the management staff are key factors affecting to pesticide business management. 


\section{RECOMMENDATIONS}

5.1. Enhancement of coordination between management agencies and organizations in monitoring, inspection and violation sanctions of pesticide business

Increasing the investment in infrastructure and facilities for the management of pesticide business, combined with the assignment of specific responsibilities to authorities at all levels (districts/ towns, communes/ wards/ townships); Promoting the coordination between communal authorities and pesticide management agencies in the inspection and monitoring activities of pesticide business; promptly detecting and handling of violations under the light of Decree 31/2016/ND-CP issued by the Government (SRV, 2016), such as the public announcement of violation cases on local radio system to increase deterrence and prevent violations; and Encouraging socialization and participation of social groups and organizations in management and supervision of pesticide business

\subsection{Strengthening the dissemination and training activities about professional skills for} pesticide traders

Increasing the quantity and quality of training activities, combined with utilization of the diverse facilities media (television, newspapers, publications, leaflets...) with the aim at popularizing the regulations on pesticide business and the list of pesticides licensed for use issued annually by the Ministry of Agriculture and Rural Development.

5.3. Improvement of the management system for pesticide business concerning both the quantity and quality of management staff

Increasing the private funds for training and researching activities for the pesticide agencies (Department of Cropping and Plant Protection; District Centers of Agricultural Services). These actions help to improve both professional knowledge and skills for management staff, and to keep them updated with new information to meet the requirements of management and constant development of agricultural production; Implementation of staff for inspection activities, which is recommended by Department of Cropping and Plant Protection according to the job position project, need to be carried out promptly with at least 05 provincial inspectors specialized in pesticides. At the district level, there is a need to increase the number of civil servants working in pesticide management. Each district should have at least 1 civil servant being in charge of inspection, supervision and monitoring of pesticide business.

\subsection{Investment in infrastructure and financial funds for management agencies}

To create favorable conditions for the performance of management activities, ensuring the impartiality and scientific correctness. In particular, it is necessary to encourage socialization of financial fund in combination with the development of programs/ projects for financial funds, equipment, facilities, scientific knowledge and technology, serving the activities of inspection, examination, training and dissemination and improving the quality of pesticide management in the province.

\subsection{Specific regulations for to practical implementation of legal documents in the province} Constantly revisiting, revising and supplementing the legal documents according to the regime "doing while reviewing, adjusting, supplementing"; Building and promulgating policies on salaries and working-trip allowances for pesticide inspectors, along with policies on emulation and commendation in the pesticide management activities at all levels. 


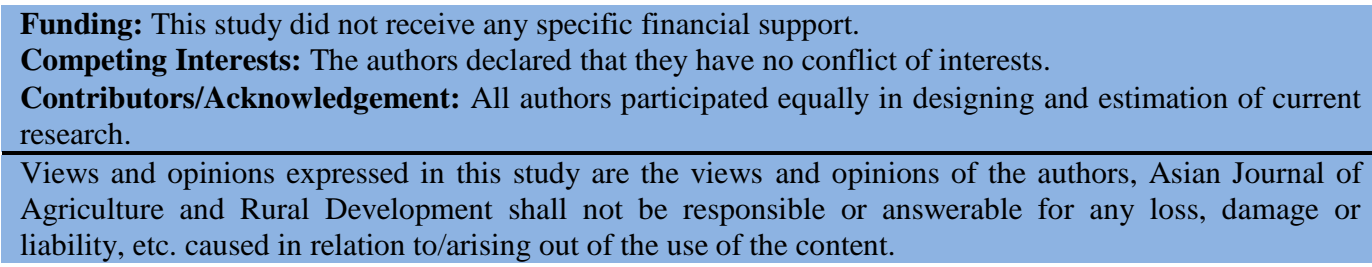

\section{References}

Adjrah, Y., Dovlo, A., Karou, S. D., Eklu-Gadegbeku, K., Agbonon, A., de Souza, C., \& Gbeassor, M. (2013). Survey of pesticide application on vegetables in the Littoral area of Togo. Annals of Agricultural and Environmental Medicine, 20(4), 715-720.

Do, K. C., Kim, T. D., Do, T. N., \& Le, T. L. (2009). Investigating Pesticide applicator's knowledge on pesticide risk reduction in vegetable production in Ha Noi and Thai Binh, Journal of Scientific Development, 7(2), 143-150.

Eyhorn, F., Roner, T., \& Specking, H. (2015). Reducing pesticide use and risks-What action is needed?. Briefing paper: Helvetas, Swiss Intercooperation. doi: 10.13140/RG.2.2.17146.80324

Fan, L., Niu, H., Yang, X., Qin, W., Bento, C. P., Ritsema, C. J., \& Geissen, V. (2015). Factors affecting farmers' behaviour in pesticide use: Insights from a field study in northern China. Science of the Total Environment, 537, 360-368. https://doi.org/10.1016/j.scitotenv.2015.07.150.

FAO (2002). International code of conduct on the distribution and use of pesticides-adopted by the hundred and twenty-third session of the FAO Council in November 2002. World Health Organisation. Rome. Italy. http://www.fao.org/3/y4544e/y4544e00.htm

Hair, J. F., Black, W. C., Babin, B. J., \& Anderson, R. E. (2009). Multivariate data analysis (7th ed.). Upper Saddle River, NJ: Prentice-Hall International.

Hair, J. F., Black, W. C., Babin, B. J., Anderson, R. E., \& Tatham, R. L. (1998). Multivariate data analysis (Vol. 5, No. 3, pp. 207-219). Upper Saddle River, NJ: Prentice-Hall.

Hoang, T., \& Chu, N. M. N. (2008). Analyzing researched data with SPSS (2nd ed.). Ho Chi Minh City, Vietnam: Hong Duc Publishing House.

Hoi, P. V., Mol, A. P., Oosterveer, P., van den Brink, P. J., \& Huong, P. T. (2016). Pesticide use in Vietnamese vegetable production: a 10-year study. International Journal of Agricultural Sustainability, 14(3), 325-338. doi.org/10.1080/14735903.2015.1134395.

Holland, P. T., \& Rahman, A. (1999). Review of trends in agricultural pesticide use in New Zealand (p. 53). Wellington, New Zealand: Ministry of agriculture and forestry. https://www.epa.govt.nz/assets/FileAPI/hsno-ar/APP201774/3f96ec8f79/APP201774Holland-and-Rahman-1999.pdf.

Mengistie, B. T., Mol, A. P., Oosterveer, P., \& Simane, B. (2015). Information, motivation and resources: The missing elements in agricultural pesticide policy implementation in Ethiopia. International Journal of Agricultural Sustainability, 13(3), 240-256. doi.org/10.1080/14735903.2014.959330.

Nguyen, P. L., \& Tran, T. N. N. (2013). State of implementation of regulations on pesticide trading management in vegetable production in the Red River Delta area. Journal of Science and Development, 11(1), 107-114.

Nguyen, T. M., Le, N. T. T., Havukainen, J., \& Hannaway, D. B. (2018). Pesticide use in vegetable production: A survey of Vietnamese farmers' knowledge. Plant Protection Science, 54(4), 203-214. doi.org/10.17221/69/2017-PPS.

Ntow, W. J., Gijzen, H. J., Kelderman, P., \& Drechsel, P. (2006). Farmer perceptions and pesticide use practices in vegetable production in Ghana. Pest Management Science: Formerly Pesticide Science, 62(4), 356-365. doi.org/10.1002/ps.1178.

SRV (2001). Plant protection and quarantine. Ordinance No. 36/2001/PL-UBTVQH10 issued on 25 July 2001. Social Republic of Vietnam, Hanoi. 
SRV (2016). Decree 31/2016/ND-CP dated May 6, 2016, of the Prime Minister on regulations on sanctioning administrative violations in the field of crop varieties. Social Republic of Vietnam, Hanoi.

Sylviane, N, V., Shanahan, M., William, J., \& Trent, S. (2002). Death in small does Cambodia's pesticide problems and solution. Environment Justice Foundation. London. UK

Thanh Hoa Plant Protection Department (2016). Report on the results of state management of pesticide management period 2011 - 2015. Report No. 140 / BC-BVTV dated June 3, 2016.

Ngo Chi, T., Le Hoang Ba, H., Hoang Thanh, H., Le Quang, H., \& Le Van, C. (2019). Linkages in modern distribution channels formation: the study of factors affecting mountainous agricultural products consumption in Vietnam. Economic Annals, 21, 178-212. doi.org/10.21003/ea.V178-12.

Tijani, A. A. (2006). Pesticide use practices and safety issues: the case of cocoa farmers in Ondo State, Nigeria. Journal of Human Ecology, 19(3), 183-190. doi.org/10.1080/09709274.2006.11905876.

Van, H. P., Mol, A. P., Oosterveer, P., \& van den Brink, P. J. (2009). Pesticide distribution and use in vegetable production in the Red River Delta of Vietnam. Renewable agriculture and food systems, 24(3), 174-185. doi.org/10.1017/S1742170509002567.

Van, H. P., Mol, A., \& Oosterveer, P. (2013). State governance of pesticide use and trade in Vietnam. NJAS-Wageningen Journal of Life Sciences, 67, 19-26. doi.org/10.1016/j.njas.2013.09.001.

Van, M. P., Cuc, N. T. T., \& Van, H. A. (2001). Farmers' knowledge, perceptions and practices in mango pest management in the Mekong Delta, Vietnam. International Journal of Pest Management, 47(1), 7-16. https://doi.org/10.1080/09670870150215559.

Williamson, S., Little, A., Ali, M. A., Kimani, M., Meir, C., \& Oruko, L. (2003). Aspects of cotton and vegetable farmers' pest management decision-making in India and Kenya. International Journal of Pest Management, 49(3), 187-198. doi.org/10.1080/0967087031000085015.

Zhou, J., \& Jin, S. (2009). Safety of vegetables and the use of pesticides by farmers in China: Evidence from Zhejiang province. Food Control, 20(11), 1043-1048. doi.org/10.1016/j.foodcont.2009.01.002. 